\title{
ETHICS - BIOETHICS - RESEARCH
}

\author{
Autor: Professor Carlos Jorge Rocha Oliveira' - Biologist CRBio 19428 / 01D - PhD in \\ Molecular Biology - São Paulo - Brazil.
}

\begin{abstract}
Every study that involves any living species of our system must be based on knowing how to differentiate ethics from moral and law. These three areas of knowledge are distinguished, but have great links and even overlaps. The following will be described some thoughts and foundations of different authors who stand on what is Ethics, Morals and Law, and their most usual definitions, as well as the usual concepts of Bioethics.
\end{abstract}

Ethics - The Greek word éthos gives rise to the word Ethics, which can be translated by custom or ownership of character. The word éthos also served for the Latin translation of Moral, while Ethics somehow guides "General inquiry into what is good." (Moore GE, Ethical Principles, São Paulo: Cultural April, 1975). The relationship between people and their achievements is intrinsically related to Ethics (...) Ethics deals with and seeks the perfection of the human being. (Clotet J. An introduction to the subject of ethics Psico 1986; 12 (1) 84-92).

Singer suggests: "Ethics can be a set of rules, principles or ways of thinking that guide, or call to itself, the authority to guide, the actions of a particular group (morality), or is the systematic study of the argument about how we should act (moral philosophy). " (Singer P. Ethics, Oxford: OUP, 1994).

Moral - The word Moral comes from the Latin Morus that brings meaning and customs to people. Moral is contained in codes, which tend to regulate people's actions. According to Augusto Comte (1798-
1857), "Morality consists in making sympathetic instincts prevail over selfish impulses."

It is understood by sympathetic instincts those that approach the individual of the others. (Roux A. La pensée d'Auguste Comte, Paris: Chiron, 1920: 254). In definition, Piaget says that "every Moral is a system of rules and the essence of all morality consists in the respect that the individual feels for such rules." (Piaget J. The moral judgment in the child, Madrid: Beltrán, 1935: 9-11).

Law - Issues involving Law and Law can be confused with the Principle of Justice. The Law realizes the social life through the Laws. Justice is a moral principle and broader than the law, usually interpreted through the view of distributive justice. Distributive justice refers to a construct related to how people evaluate the distributions of positive assets (income, freedom, political positions) or negatives (punishments, sanctions, penalties) in society. (Leonardo Rodrigues Sampaio, Cleonice P. Santos Camino, Antônio Roazzi) Distributive justice: a review of the psychoso-

${ }^{1}$ Corresponding Author:

Carlos Jorge Rocha Oliveira: e-mail: porfcj52@gmail.com - https://orcid.org/0000-0003-2577-8751

DOI: https://doi.org/10.31415/bjns.v2i2.61 - Article received on: August 25, 2019; accepted September 05, 2019; published September 30, 2019. Brazilian Journal of Natural Sciences, Vol. 2, N.3, September 2019. Available online September, 2019, ISSN 2595-0584. www.bjns.com.br - All authors contributed equally with the article. Author declares no conflict of interest. This is an open access article under the CC-BY license:

http://creativecommons.org/licenses/by/4.0 
cial and developmental literature. 2009). "Do not forget that what is fair from the legal point of view may not be from the moral point of view." (Abraham Lincoln (1809-1865)

Bioethics - Potter 1970: The article "Bioethics, the science of survival" presents a text adapted from chapter I of the book Bioethics: bridge to the future, which was still in print, having been published in January 1971 and says:

"We have a great need for a Land Ethics, an Ethics for Wildlife, a Population Ethics, an Ethics of Consumption, an Urban Ethics, an International Ethics, a Geriatric Ethics and so on ... All of them involve the bioethics, (...) "(Potter (1970).

This was the first text suggesting the term Bioethics. $\mathrm{PhD}$ in Biochemistry, researcher and professor in the field of Oncology at McArdle Laboratory, University of Wisconsin / USA Prof. Van Rensselaer Potter was very concerned about the environmental problem and the repercussion of the model of progress advocated in the 1960s. This definition has evolved into the Global Ethics (Global Ethics or Global Bioethics), made in 1988. (Potter VR Bioethics, The Science of Survival, Perspectives in Biology and Medicine 1970, 14: 127-153).

\section{Bioethics - Potter in 1971:}

"I propose the term Bioethics as a way of emphasizing the two most important components to attain a new wisdom that is so desperately needed: biological knowledge and human values."

Bioethics is a bridge between science and the humanities. (Potter VR, Bioethics, Bridge to the Future, Englewood Cliffs: Prentice Hall, 1971: 2).

\section{Bioethics - Potter in 1988:}

"Bioethics is the combination of biology with a variety of humanistic knowledge as a science that establishes a system of medical and environmental priorities for acceptable survival." (Potter VR Global Bioethics Building on the Leopold Legacy East Lansing Michigan State University Press, 1988).

Principle of Respect for the Person or Autonomy - This principle is central to Bioethics and establishes itself in privacy and truthfulness.

The thought of John Stuart Mill (1806-1883) proposes that: "about himself, about his body and his mind, the individual is sovereign."

The Belmontreport (1978) proposed that autonomy incorporates at least two ethical convictions: first that individuals should be treated as autonomous agents, and second, that people with diminished autonomy should be protected.

The Belmont Report sets out the ethical principles, considered basic, that should guide biomedical research with human beings: a) the principle of respect for people; b) the principle of beneficence; c) the principle of justice. also proposed that autonomy incorporates at least two ethical convictions: first that individuals should be treated as autonomous agents, and second, that people with diminished autonomy should be protected. (The Belmont Report: Ethical Guidelines for the Protection of Human Subjects. Washington: DHEW Publications (OS) 78-0012, 1978).

Beauchamp and Childress, reduced the Principle of Respect to the Person for Autonomy. These authors admit that "autonomy has different meanings, as diverse as self-determination, right of freedom, privacy, individual choice, free will, behavior generated by the individual himself and being a person."

The concept of Autonomy acquires specificity in the context of each theory. Virtually all theories agree that two conditions are essential to autonomy: freedom (independence of control of influences) and action (ability to act intentionally). (Beauchamp TL, Childress JF, Principles of Bioethical Ethics, 4d. New York: Oxford, 1994: 100-103).

\section{Beneficence}

"The principle of beneficence requires that all people be treated ethically, that their decisions are respected and that they be protected from harm." Two rules are suggested: 1) do no harm, and 2) maximize possible benefits and reduce possible (Barchifontaine and Pessini, 2009, p.573).

In Brazil all these themes are grouped in committees of ethics that are notable for establishing the norms and conduct for the different lines of research. Research involving directly or indirectly human beings is established by resolution CNS 466/12. The studies and research involving animals are established by the National Council for the Control of Animal Experimentation in compliance with Arouca Law No. 11,794, of October 8, 2008.

Research is to plan, reflect, act and observe. As a 
starting point we can stick to two initial proposals: 1) An adequate methodology to achieve the objective response. 2) Let the research add to the knowledge more about the subject studied. (Kemmis and McTaggart (1988).

In general research must be based on concepts where the search for results reach social, moral and ethical values for all. Human dignity, human rights and fundamental freedoms must be respected in their entirety in any research. There is no research without respect!

\section{Bibliography}

MOORE GE. Ethical Principles. São Paulo: Cultural April, 1975.

SINGER P. Ethics. Oxford: OUP, 1994

ROUX A. La pensée d'Auguste Comte. Paris: Chiron, 1920: 254.

PIAGET J. The moral judgment in the child. Madrid: Beltran, 1935: 9-11.

LEONARDO Rodrigues Sampaio; Cleonice P. Santos Camino; Antônio Roazzi. Distributive justice: a review of the psychosocial and developmental literature. Psychology in study, Maringá, v. 14, n. 4, p. 631-640, Oct./Dec. 2009.

POTTER VR. Bioethics, the science of survival. Perspectives in biology and medicine 1970; 14: 127153.

POTTER VR. Bioethics. Bridge to the future. Englewood Cliffs: Prentice Hall, 1971: 2.

BELMONT Report: Ethical Guidelines for the Protection of Human Subjects. Washington: DHEW Publications (OS) 78-0012, 1978).

BEAUCHAMP TL, Childress JF. Principles of Bioemical Ethics. 4ed. New York: Oxford, 1994: 100-103.

Barchifontaine C. de P, Pessini, L. Current issues of bioethics. 9. Ed. São Paulo. Ed. Loyola, 2009. 